\title{
Observações sobre a entoação das sentenças SV em português brasileiro*
}

\author{
Observations on the intonation of SV sentences in \\ Brazilian Portuguese
}

\section{Maria Cristina Figueiredo Silva \\ UFSC \\ Izabel Christine Seara \\ UFSC}

\begin{abstract}
Our main goal in this paper is to discuss the intonational pattern of SV sentences when used in the so-called neutral contexts - that is, sentences that do not contain focus on any of their constituents. The hypothesis to be verified here is whether it is possible to identify two different intonational patterns in $\mathrm{SV}$ sentences. In the case of a positive answer, we have to ask if the difference in pitch contours is correlated with verbal classes (inergative and unaccusative) and/or types of DP (definite and indefinite). The hypothesis is relevant because (a) SV sentences must be able to convey different informational structures in non-freeinversion languages; and (b) Brazilian Portuguese is not a free inversion language anymore. More ambitious hence is to ask if it is possible to relate these two different intonational patterns in SV sentences to interpretative differences between them.
\end{abstract}

\section{Keywords}

Intonation, SV sentences, Brazilian Portuguese. 


\section{Resumo}

Nosso objetivo principal neste trabalho é discutir o padrão entoacional de sentenças SV quando usadas nos chamados contextos neutros - isto é, sentenças que não contêm foco em nenhum de seus constituintes. A hipótese a ser verificada aqui é se é possível identificar dois padrões entoacionais diferentes nas sentenças $\mathrm{SV}$ e, em caso afirmativo, se a diferença nos contornos de pitch está relacionada com classes verbais (inergativos e inacusativos) e/ou tipos de DPs (definidos e indefinidos). A questãoé relevante porque sentenças SV devem ser capazes de veicular estruturas informacionais diferentes em línguas que não admitem inversão livre do sujeito e o português brasileiro não é mais uma língua de inversão livre do sujeito. Mais ambicioso, então, é perguntar se é possível relacionar estes dois diferentes padrões entoacionais em senteças SV com diferenças interpretativas.

\section{Palavras-chave}

Entoação, Sentenças SV, Português brasileiro. 


\section{INTRODUÇÃO}

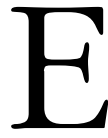

ste trabalho tem por objetivo primeiro discutir o padrão entoacional de sentenças SV com diferentes tipos de verbos no português brasileiro (doravante PB), quando utilizadas em contextos ditos neutros. Em princípio, estas seriam sentenças que não apresentam foco em nenhum de seus constituintes, veiculando informação completamente nova, como é o caso de uma manchete de jornal, da resposta a uma pergunta como o que aconteceu? ou da apresentação de uma situação por um falante. Interessa-nos particularmente responder à seguinte questão: diferentes melodias são possíveis para as frases SV nesse contexto?

O interesse nessa questão se deve a duas asserções distintas que se encontram na literatura especializada. Segundo a primeira delas, mesmo quando a sentença descreve um fato novo, SV poderia veicular diferentes estruturas informacionais: uma em que o sujeito é interpretado como tópico discursivo e outra em que não é. A observação que remonta a Schmerling (1976, citada por CINQUE, 1993) é de que, em línguas como o inglês, a estrutura SV neutra disporia de duas estruturas acentuais distintas: a que apresenta o acento sentencial na sua posição canônica (à direita da sentença) trata o sujeito como parte da pressuposição; a mudança da posição do acento nuclear para o início da sentença, sobre o sujeito portanto, responderia pela interpretação em que o sujeito não é tópico discursivo. Hipotetizaremos aqui que a mudança no lugar do acento nuclear numa estrutura SV leva a mudança na melodia da sentença, perceptível no exame do seu contorno de pitch.

Uma observação de Cinque (1993) acoplada a essa observação de Schmerling diz respeito a como o italiano, uma língua de sujeito nulo e inversão livre do sujeito, veicula estas duas estruturas informacionais que se utilizam de mudança na posição do acento em inglês: a estrutura que toma o sujeito como parte da pressuposição é a estrutura SV; no entanto, quando o sujeito não deve ser tratado como tópico discursivo, é a opção VS que é usada. 
A outra asserção é específica sobre o PB: afirma-se que essa língua não é mais uma língua de inversão livre do sujeito, uma propriedade que veio se perdendo ao lado da perda da propriedade do sujeito nulo (cf., dentre outros, BERLINCK, 1988; KATO, 2000; KATO e TARALLO, 2003). Assim, o PB não dispõe mais consistentemente de VS. O último contexto em que se admite a ordem VS são as estruturas com verbos inacusativos, preferidas quando o DP sujeito é indefinido.

A hipótese a ser verificada aqui, portanto, é se é possível identificar dois padrões entoacionais distintos para as sentenças SV do PB e se esses padrões estão presentes em qualquer sentença SV independentemente do tipo de verbo - inergativo ou inacusativo - e do tipo de DP sujeito - definido ou indefinido. Um objetivo mais ambicioso, para o qual talvez tenhamos por agora apenas uma indicação, é saber se, no caso de o PB apresentar dois padrões melódicos distintos para as sentenças SV, é possível identificar contextos discursivos diferentes em que cada um desses padrões seja favorecido.

Este estudo se estrutura da seguinte maneira: na seção 2, fazemos uma breve apresentação da interface fonologia-sintaxe, centrando a discussão nos pontos cruciais para a nossa argumentação, já que estaremos falando também de dois modelos fonológicos distintos: a literatura sintática faz menção à fonologia métrica (que responde pelo lugar do acento nuclear da sentença), mas aqui estaremos acrescentando à discussão os ganhos da fonologia entoacional, que busca determinar o padrão melódico da sentença, observando as mudanças nos seus contornos de pitch. Na seção 3, apresentamos a metodologia para a construção do nosso corpus e para a análise dos dados, e igualmente os resultados dos nossos experimentos de base. A seção 4 apresenta a discussão sobre diferentes estruturas acentuais e os diferentes padrões entoacionais de SV, momento em que confrontaremos os dados obtidos em testes com o PB com os dados de outras línguas. Finalmente, a seção 5 apresenta as conclusões deste estudo e certas direções futuras na pesquisa sobre o tema.

\section{BREVE APRESENTAÇÃO DA INTERFACE FONOLOGIA-SINTAXE}

O estudo de interfaces nunca é matéria trivial. A questão não é simplesmente a de compatibilizar dois vocabulários advindos de fontes de conhecimento distintas, por si só já um problema espinhoso; a questão é, 
sobretudo, a de colocar dois campos de conhecimento em uma relação articulada de tal modo que certas conclusões sobre uma das interfaces possam servir de argumento para sustentar hipóteses a respeito de fenômenos vários na outra interface, o que implica fazer algumas hipóteses e tomar decisões sobre a estrutura mesma da gramática.

Dentro do arcabouço gerativista, entendemos a interface entre a fonologia e a sintaxe como um percurso que vai da direção da sintaxe para a fonologia: dado o modelo em $\mathrm{T}$ das versões mais tradicionais da gramática gerativa, como o de Chomsky (1981), toda a sintaxe é computada antes de qualquer processo fonológico ${ }^{1}$. Aqui vamos assumir que a sintaxe de uma língua tem possibilidade de gerar certas estruturas (que estarão disponíveis para veicular esta ou aquela estrutura informacional). Se a sintaxe não disponibiliza uma certa variedade de estruturas em seu output, a fonologia deverá se encarregar de gerar por seus próprios meios diferentes configurações fonológicas capazes de expressar as diferenças semânticas ou discursivas relevantes (cf. COSTA e FIGUEIREDO SILVA, 2006).

No entanto, ainda é preciso se perguntar como a fonologia lê as estruturas sintáticas. Existem várias teorias fonológicas destinadas a tratar de diferentes fenômenos que são, em última análise, problemas provenientes da interface com a sintaxe. De interesse imediato aqui é a fonologia métrica, que trata da distribuição do acento nas sentenças, e a fonologia entoacional, que procura determinar como o padrão melódico que percebemos nas sentenças pode ser descrito com base no que ocorre com mudanças na freqüência fundamental $\left(\mathrm{F}_{0}\right)$ em diferentes pontos da sentença.

Vamos examinar mais de perto cada uma dessas teorias fonológicas, tentando já apontar como cada uma delas se relaciona com a estrutura sintática. No que diz respeito à fonologia métrica, o estudo de Cinque (1993) é talvez o mais simples para os sintaticistas, já que este autor entende a distribuição de acento frasal como um mecanismo basicamente sintático, segundo o qual o acento mais proeminente da sentença é aquele que cai sobre o elemento mais encaixado dela, do lado recursivo de encaixamento da língua. A esse mecanismo gramatical de atribuição de acento frasal podem se sobrepor posteriormente outros, discursivos, por exemplo, como fruto de exigências da estrutura informacional do enunciado (quando há foco marcado ou ênfase na sentença, por exemplo). Vê-se, assim, uma proposta de interface em que a fonologia basicamente lê as informações provenientes da sintaxe, só promovendo alterações nos casos em que o discurso as exige. 
A título de ilustração, podemos ver como se daria a atribuição de acento frasal em uma sentença como (1) - estamos citando o exemplo (15) de Cinque (1993, p. 246):

(1)

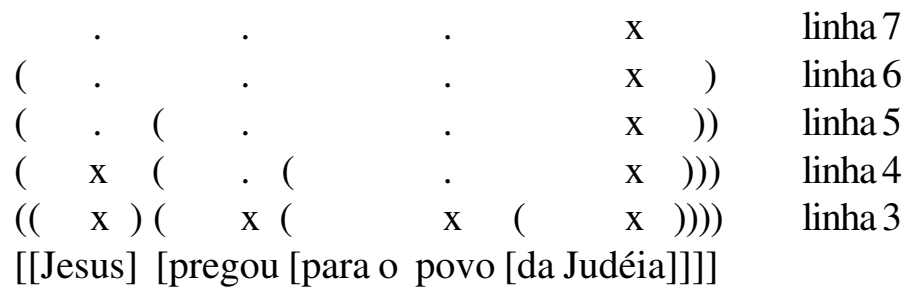

Até a segunda linha é o acento da palavra que está sendo computado; o mecanismo de distribuição de acento frasal começa a atuar a partir da terceira linha, na qual a estrutura sintática aparece representada pela parentetização. Cada linha é o resultado da computação do acento no constituinte mais interno ali presente, tendo sempre por base o que se passou na linha precedente, até que a computação alcance o constituinte mais externo - a sentença toda. Cinque não adota a hipótese do sujeito engendrado dentro do VP, e assim o DP sujeito e o VP passam por dois ciclos separados antes de se juntarem na sentença, de modo que o sujeito ainda recebe um asterisco na linha 4 , representando a proeminência sensível do sujeito frente ao verbo, um fato observável nas línguas em geral.

Podemos agora nos perguntar que correlatos físicos são responsáveis pela percepção da proeminência do acento lexical ou sentencial. Os estudos sobre o tema (cf. MORAES, 1998) nos indicam que o acento não tem um correlato físico único, mas vários: a intensidade, a duração e a frequiência fundamental são seus correlatos, mas a importância de cada um desses correlatos depende da posição da palavra no grupo prosódico no qual se encontra. No que tange ao acento frasal, a freqüência fundamental $\left(\mathrm{F}_{0}\right)$ é o correlato mais importante, indiretamente também fornecendo evidência para o acento lexical.

Por outro lado, segundo a Fonologia Entoacional (cf. LADD, 1996), a entoação de uma sentença pode ser descrita por uma análise que interpreta a freqüência fundamental $\left(\mathrm{F}_{0}\right)$ como uma seqüência de eventos fonológicos discretos, minimamente compostos por dois tipos de eventos tonais: os acentos tonais (pitch accents) e os tons de fronteira (boundary tones). $\mathrm{O}$ acento tonal se define como o tom associado à sílaba acentuada (definida independentemente 
do contorno entoacional), marcado formalmente por um asterisco. Esses tons podem ser simples (alto: $\mathrm{H}^{*}$; baixo: $\mathrm{L}^{*}$ ) ou complexos $\left(\mathrm{LH}^{*}, \mathrm{~L}^{*} \mathrm{H}, \mathrm{HL}^{*}, \mathrm{H}^{*} \mathrm{~L}\right.$ ), quando se observam mudanças súbitas de contorno imediatamente antes ou depois do lugar em que está o acento. Os tons de fronteira, formalmente marcados como $\mathrm{L} \%$ (ou Li) e $\mathrm{H} \%$ (ou Hi), marcam as fronteiras de constituintes prosódicos, aqui tomados como idênticos aos constituintes sintáticos, o que seguramente não é correto, mas é o bastante para os dados que estarão em discussão.

Para ilustrar seu uso, tomemos o padrão entoacional de uma frase declarativa neutra SVO do PB: segundo Tenani (2002, p. 35), ele se caracteriza por apresentar o acento principal da sentença sempre sobre a última sílaba acentuada (como previsto pelo algoritmo de Cinque), exibindo aí um evento tonal $\mathrm{H} \mathrm{L}^{*}$, em que o tom $\mathrm{L}$ é alinhado à sílaba tônica e o tom $\mathrm{H}$ é alinhado com a sílaba imediatamente precedente. Também é observável um tom de fronteira Li, ausente apenas quando a última sílaba acentuada ocupa a posição final do enunciado. Ainda segundo Tenani (2002, p. 40), o enunciado declarativo neutro se caracteriza igualmente pela presença de um evento bitonal inicial do tipo $\mathrm{LH}^{*}$, que pode ser precedido por um tom $\mathrm{H}$ se antes da sílaba acentuada inicial existirem quatro ou mais sílabas pretônicas. Os exemplos apresentados em (2a) e (2b) foram extraídos de Tenani (2002, p. 36,44), correspondendo aos exemplos (4.1) e (6.3) da autora, respectivamente:

(2) a. O menino gostou do presente.

\section{LH* H L* $\mathbf{H}^{*} \mathbf{L} * \mathbf{L i}$}

b. A pesquisadora terminou os trabalhos.
$\mathrm{H}$
LH*
$\mathrm{L}^{*}$
H L* Li

Para que a exposição fique completa, devemos ressaltar ainda que, em termos de desenho geral da curva entoacional, uma sentença declarativa neutra apresenta sempre uma seqüência de eventos descendentes, o que quer dizer que pode acontecer de o $\mathrm{H}$ do final da frase já se encontrar num patamar mais baixo (em termos de $\mathrm{Hz}$ ) do que o L do início da sentença. Um pouco mais à frente mostraremos a figura de uma sentença transitiva declarativa neutra, momento em que essa descrição fará mais sentido para o leitor. 
Por outro lado, nas situações em que há foco marcado, conforme Cinque (1993), o procedimento de atribuição de acento gramatical é superado por um outro procedimento de atribuição de acento, que, segundo Selkirk (1995), é a atribuição de um acento de pitch, que muda o contorno da sentença; assim, este é um contexto em que o lugar de maior proeminência perceptual da frase é exatamente o lugar do acento de pitch. Gonçalves (1999), tratando da focalização, afirma que esse fenômeno pode ser expresso unicamente por parâmetros suprassegmentais, tentando mostrar também que a sintaxe não é o principal módulo para a exteriorização do fenômeno da focalização.

No caso dos fenômenos que serão analisados aqui, a marcação fonológica da focalização de algum constituinte não será o ponto mais importante, já que estaremos lidando principalmente com sentenças que veiculam informação nova - portanto, toda a sentença seria foco, não algum de seus elementos. No entanto, mesmo quando esse é o caso, é possível que haja certas informações na sentença que já estejam presentes no contexto discursivo anterior. A pergunta então é se existe alguma estratégia para marcar fonologicamente a expressão de tópicos discursivos e, em caso afirmativo, como essa estratégia se revela em termos de distribuição do acento sentencial da frase em questão e que tipo de conseqüência ela pode ter sobre o movimento de pitch que se observa na frase.

Observamos finalmente que, para este estudo, não utilizaremos nenhuma descrição tonal específica. O que é necessário para a discussão que queremos fazer é muito mais o contorno geral de pitch que está em jogo na frase - por exemplo, onde está seu movimento principal, se sobre o sujeito ou sobre o VP - do que a discussão mais detalhada dos eventos em um certo ponto específico da sentença. Assim, utilizaremos termos gerais como "movimento de pitch sobre o sujeito", querendo com isso dizer que é observável um conjunto de eventos tonais, como uma subida e uma descida de altura, por exemplo, no constituinte em discussão. É evidente que, num trabalho futuro, o detalhamento dos eventos tonais presentes nestas observações sobre os padrões gerais que estamos tentando estabelecer aqui deverá ser contemplado. 


\section{METODOLOGIA}

\subsection{A construção dos corpora}

Para o estudo que pretendemos desenvolver, devemos antes de mais nada perguntar se o padrão entoacional de uma frase declarativa neutra SV é idêntico ao padrão de uma sentença declarativa neutra SVO, já que a descrição que apresentamos em (2), extraída de Tenani (2002), diz respeito a sentenças transitivas ${ }^{2}$. É necessário, portanto, uma descrição prévia das estruturas SV.

As perguntas que nos interessam mais especificamente, no entanto, são aquelas que estão em (3):

(3) a. Há alguma diferença perceptível em termos de entoação interna ao tipo sentencial SV diferenciando os verbos inacusativos dos verbos inergativos?

b. Há alguma diferença perceptível em termos de entoação interna ao tipo sentencial SV diferenciando tipos de DPs sujeitos como DPs definidos e indefinidos?

A razão pela qual é importante respondermos a essas questões se liga ao fato de já ter sido notado na literatura especializada - por exemplo, no trabalho de Cinque (1993) que discutiremos aqui, mas também no de Sandalo e Truckenbrodt (2002) e Sandalo (2004), que abordam o português brasileiro - que as orações com verbos monoargumentais não se comportam exatamente da mesma maneira que as orações construídas com verbos transitivos com respeito a diferentes fenômenos fonológicos, o que inclui distribuição de acento frasal e fenômenos de retração de acento. E já que em sintaxe dizemos que os verbos monoargumentais constituem duas classes distintas, não é descabido perguntar se eles também se diferenciam com respeito a qualquer propriedade fonológica da frase da qual participam.

Adicionalmente, é uma observação corrente em sintaxe que, com os verbos inacusativos, certas construções são mais aceitáveis se exibem um DP indefinido do que um DP definido, como é o caso de construções com inversão do sujeito. A observação contrária também encontra algum respaldo na literatura: DPs definidos parecem mostrar larga preferência pela posição préverbal, mesmo nas línguas que aceitam com naturalidade até nomes próprios na posição invertida. 
Para responder às questões colocadas em (3), submetemos três falantes nativos do português brasileiro, todos do sexo feminino, na faixa etária entre 25 e 35 anos, à gravação de três grupos distintos de sentenças. O primeiro (Corpus I) é um grupo de 12 sentenças apresentadas em pares perguntaresposta, e a tarefa do informante seria ler a sentença como se ela fosse a resposta para a pergunta acoplada; o segundo (Corpus II), um grupo de 30 sentenças para serem lidas como se fossem manchetes de jornal (os falantes eram instruídos a ler as sentenças da maneira mais natural possível). Finalmente, um terceiro grupo (Corpus III) descrevia oito contextos discursivos, e a tarefa do informante seria ler em voz alta a sentença final depois de ler silenciosamente o pequeno texto que a antecedia. Em cada um dos grupos foram controlados os diferentes tipos de verbos (transitivos, inergativos e inacusativos) e diferentes tipos de DPs sujeitos (definidos e indefinidos), com o objetivo de verificar se existe qualquer diferença sistemática no padrão entoacional que leve em conta esses dois fatores. O questionário usado para os testes se encontra no anexo 1.

As gravações foram elaboradas com o auxílio de um software de áudioprocessamento bastante flexível, o programa PRAAT (versão 4.1.21 de Paul Boersma e David Weenink), em uma sala sem ruído. A taxa de amostragem dos dados gravados foi de $11 \mathrm{kHz}$ (taxa suficiente para as análises de contorno de pitch), com 16 bits e mono.

As 150 sentenças foram então processadas pelo programa Momel-Intsint for Praat/Windows de Cyril Auran. Desse processamento, obtivemos pelo Momel a análise sintetizada das frases a partir de suas medidas acústicas de $\mathrm{F}_{0}$. O uso do Momel tem como objetivo evitar uma certa subjetividade já que as análises "manuais" dos eventos tonais são feitas com base na audição e numa interpretação dos contornos visíveis de pitch, cujos desenhos nem sempre são suficientemente claros a ponto de permitir sistematicidade de análise. Utilizando em nosso estudo um sintetizador de padrões entoacionais, estamos em condições de obter uma descrição mais consistente dos dados, pois o descritor automático, em sua síntese, transforma as curvas entoacionais em retas com certos pontos-alvo, o que facilita a análise de contorno de pitch. Assim, os efeitos que parecerem recorrentes provavelmente não estarão associados a problemas de avaliação subjetiva. No entanto, para que tenhamos certeza da qualidade da síntese, faremos escutas avaliando se não houve alteração na versão sintetizada em relacão à frase original. 
Na Figura 1, pode ser visto um exemplo da análise processada pelo Momel, comparada à curva de pitch apresentada pelo Praat.

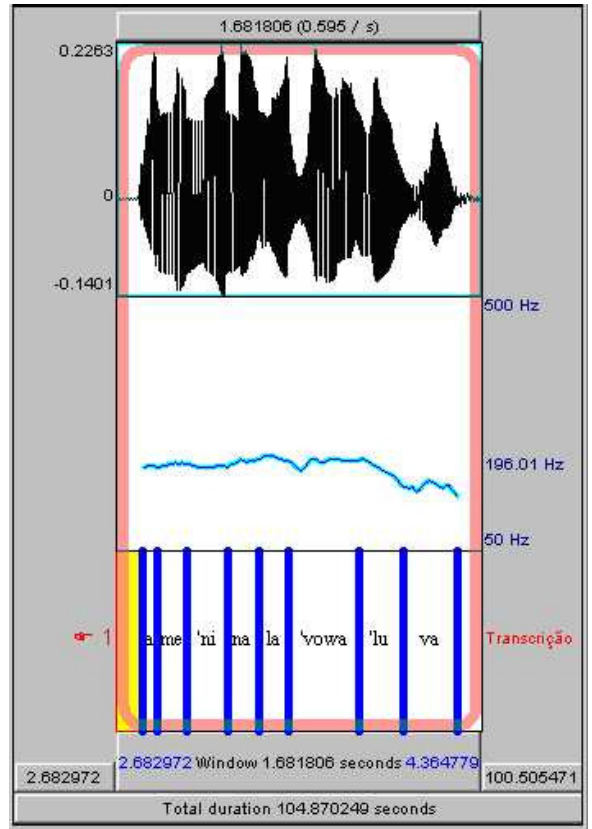

(a)

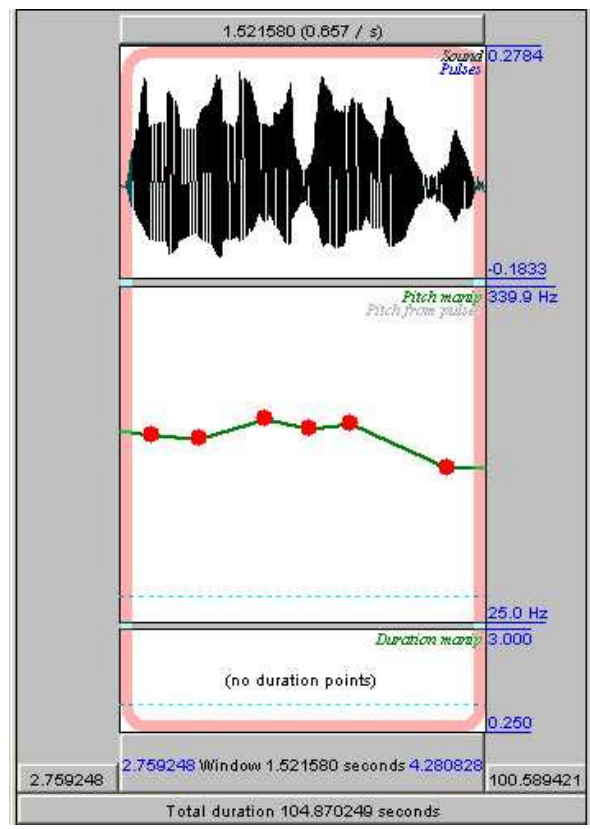

(b)

FIGURA 1

(a) Forma de onda e curva de contorno de pitch original com transcrição fonética ${ }^{3} \mathrm{e}$ (b) curva estilizada pelo Momel da sentença: A menina lavou a luva.

Ainda que esse método não tenha sido usado em outros estudos da entoação do português - por exemplo, os de Tenani (2002) e Frota (1998) , é bastante claro que ele nos permitirá consistência na análise de todos os dados. 


\subsection{Primeiros resultados sobre o padrão SV}

Pesquisas sobre a entoação do PB não são abundantes na literatura. É certo que vários estudiosos já construíram um corpo de conhecimento sólido sobre alguns fenômenos (cf., por exemplo, os trabalhos de Moraes, seus alunos e associados e as referências citadas nestes trabalhos), mas ainda assim a cobertura em termos de número de fenômenos ainda é pequena. Em particular, sabe-se pouco sobre o funcionamento da interface de certos processos entoacionais e a sintaxe, por um lado, e o discurso, por outro. Por essa razão, apresentaremos todos os resultados que obtivemos na testagem dos diferentes tipos de sentenças, mesmo aqueles que não são diretamente pertinentes para o nosso ponto de interesse central.

Pela mesma razão, é importante explicitarmos os motivos que nos levaram a elaborar um corpus como o testado aqui. O intuito da primeira bateria de testes (leitura da resposta a uma pergunta) era determinar como cada falante produz sentenças que, em princípio, não veiculam nenhum tipo de foco (as que são resposta a $o$ que aconteceu?) e sentenças que veiculam foco sobre o sujeito (como no caso da resposta a quem morreu? ou quem nadou?). ${ }^{4}$

O primeiro resultado que podemos apresentar, portanto, diz respeito a como a estrutura de foco sobre o sujeito é realizada, quando comparada com a estrutura que, em princípio, não apresenta foco sobre nenhum de seus constituintes. É bastante nítido que o foco nessa posição implica a presença de um movimento de pitch de clareza indiscutível sobre o sujeito. O resto da sentença se realiza numa outra faixa de pitch, mais baixa, configurando possivelmente o que Zubizarreta (1998) chama de "constituinte metricamente invisível", fenômeno fonológico que tem como correlato fonético a mudança de tessitura (cf. TENANI, 2002). A Figura 2 mostra uma sentença transitiva com foco sobre o sujeito. 


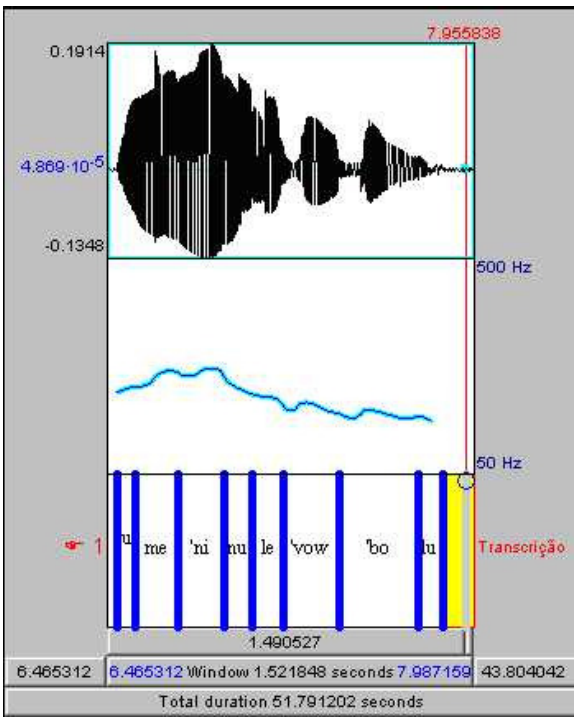

(a)

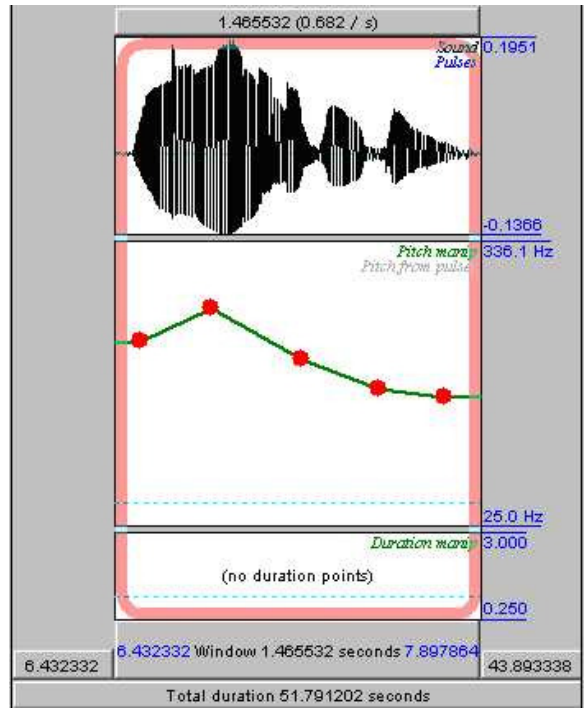

(b)

FIGURA 2

(a) Forma de onda e curva de contorno de pitch original com transcrição fonética e

(b) curva estilizada pelo Momel da sentença: Um menino levou o bolo (como resposta a quem levou o bolo?)

Aqui temos uma espécie de teste de controle, para sabermos se o falante em outras elocuções estaria ou não produzindo sentenças focalizadas, já que o nosso objeto central de estudo são as sentenças ditas neutras, por exemplo, as que são produzidas como resposta a questões do tipo o que aconteceu? Surpreendente são os padrões obtidos nas sentenças resposta a essa questão segundo o tipo de verbo: basicamente, os verbos transitivos fornecem o padrão descendente usual, já descrito na literatura e apresentado na Figura 3: há movimentos de pitch tanto sobre o sujeito quanto sobre o objeto, com o primeiro sempre mais alto que o segundo, um fato que independe do tipo de DP sujeito (definido ou indefinido). 


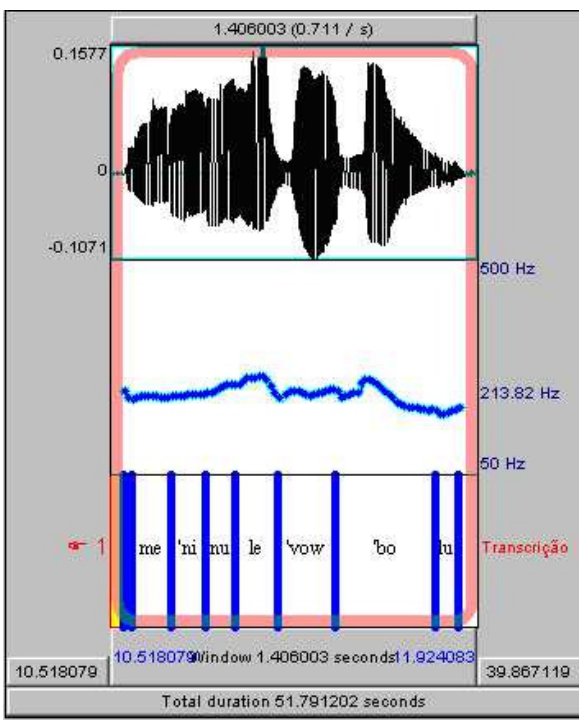

(a)

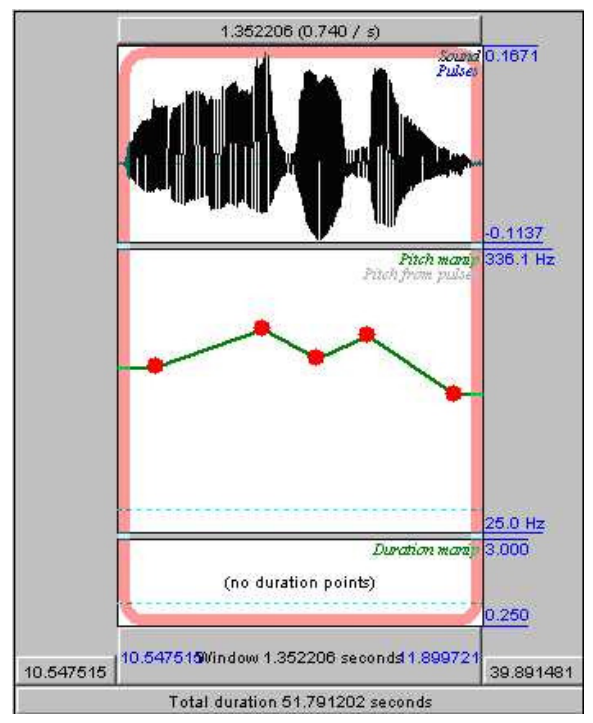

(b)

FIGURA 3

(a) Forma de onda e curva de contorno de pitch original com transcrição fonética e (b) curva estilizada pelo Momel da sentença: Um menino levou o bolo (como resposta à pergunta: $O$ que aconteceu?).

Para as sentenças com verbos inergativos, no entanto, os falantes parecem preferir um padrão ligeiramente ascendente, em que o maior movimento de pitch se encontra sobre V, como mostra a Figura 4. Uma vez mais, esse contorno independe do tipo de DP que ocupa a posição de sujeito.

Igualmente, as sentenças com verbos inacusativos exibem maior movimento de pitch sobre o verbo, mas apresentam um movimento também sobre o sujeito, configurando uma situação de movimento duplo, que o leitor pode observar na Figura 5. Nesse caso, é indiferente para o padrão entoacional da sentença o tipo de DP sujeito que ela apresenta. 


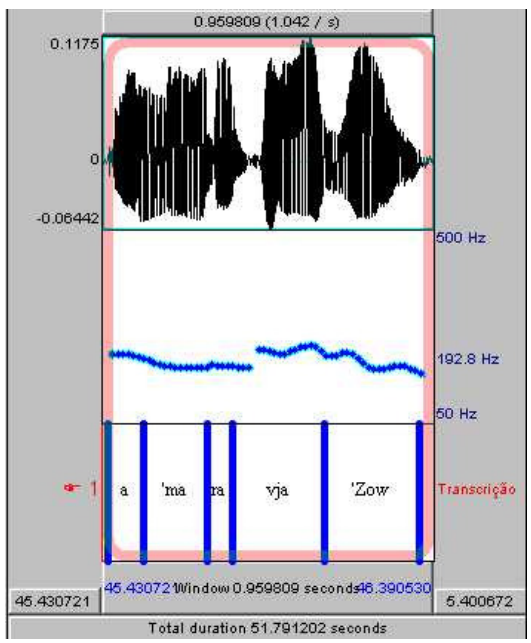

(a)

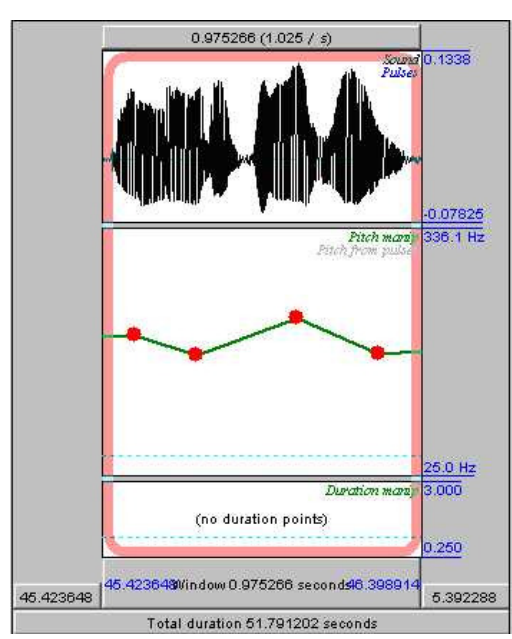

(b)

(a) Forma de onda e curva de contorno de pitch original com transcrição fonética e (b) curva estilizada pelo Momel da sentença: A Mara viajou (como resposta à pergunta: $O$ que aconteceu?).

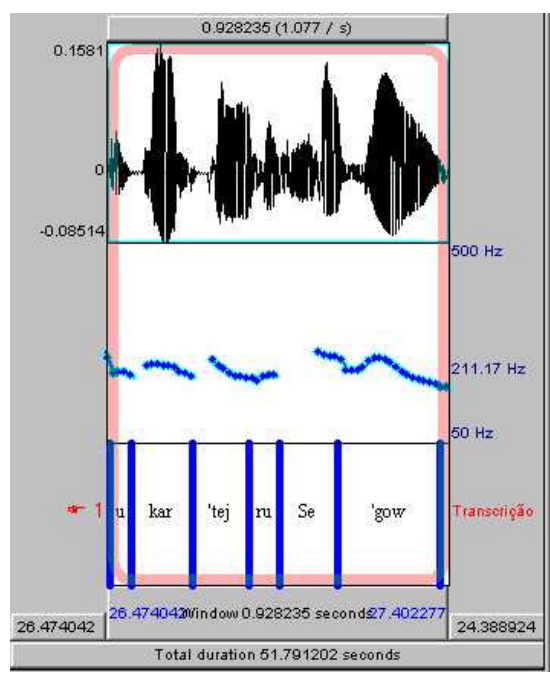

(a)

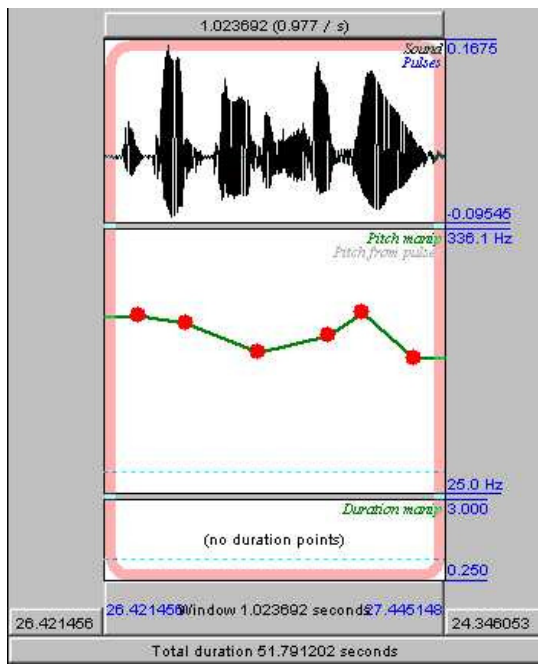

(b)

FIGURA 5

(a) Forma de onda e curva de contorno de pitch original com transcrição fonética e (b) curva estilizada pelo Momel da sentença: $O$ carteiro chegou (como resposta à pergunta: $O$ que aconteceu?). 
É uma possibilidade que estes contornos obtidos aqui sejam um tanto forçados, talvez fruto do fato de as sentenças terem sido agrupadas de tal modo que o falante lia a "mesma" sentença duas vezes seguidas, uma como resposta a quem VP? e outra como resposta a o que aconteceu? Portanto, para marcar a diferença entre elas, é possível que o falante ora focalizasse o sujeito, ora o verbo. Em experimentos anteriores, havíamos observado que as sentenças em princípio neutras exibiam padrões variados, às vezes com movimento de pitch sobre o sujeito, às vezes sobre o verbo, mas aqueles experimentos não conseguiram apresentar uma imagem tão definida porque neles os testes não controlavam com precisão o número de sentenças com os diversos tipos de verbos e de diferentes tipos de DP sujeito e nem mesmo controlavam com muita precisão a presença de foco em algum dos constituintes. ${ }^{5}$

Aqui esses fatores estão todos sob controle. Todavia, o que efetivamente nos indica que estamos diante de uma generalização robusta é o resultado que obtivemos no teste do corpus II, composto por uma bateria de trinta sentenças que deveriam ser lidas da maneira mais natural possível como se fossem manchetes de jornal. Em princípio, este seria um contexto igualmente "neutro", no sentido de não implicar foco em qualquer dos constituintes frasais. Portanto, o que esperaríamos aqui são resultados que espelhassem os obtidos como resposta a que aconteceu? O gráfico 1 mostra os resultados parciais deste teste, incluindo apenas DPs sujeito definidos.

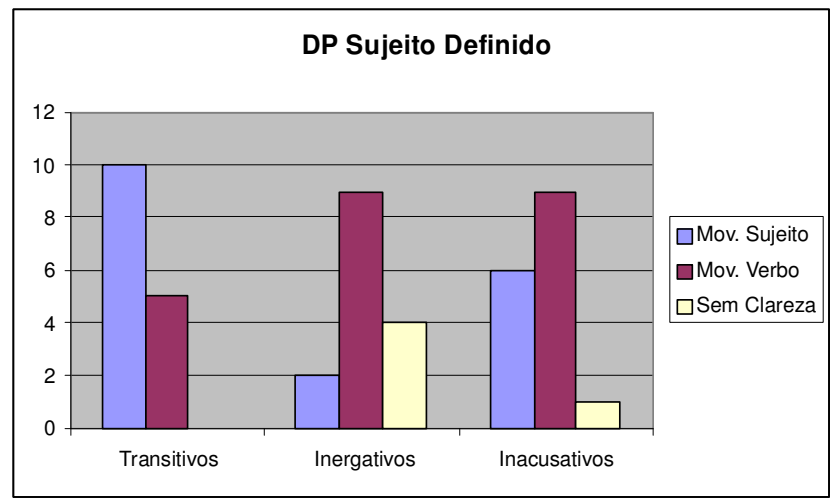

GRÁFICO 1

Número absoluto de realizações do maior movimento de pitch sobre os diferentes constituintes das sentenças formadas com verbos transitivos, inergativos e inacusativos e DPs sujeito definidos. 
O que o Gráfico 1 mostra é uma tendência dos verbos transitivos para apresentarem movimento maior de pitch sobre o sujeito, podendo ocorrer em $1 / 3$ das vezes também o movimento mais amplo de pitch sobre o verbo. Em contrapartida, verbos inergativos e inacusativos exibem tendência para mostrarem um movimento de pitch mais pronunciado sobre o verbo, diferindo entre si na proporção de vezes em que podem mostrar movimento de pitch sobre o sujeito (os casos anotados como "sem clareza" no gráfico dizem respeito a curvas muito planas, que nem o Momel consegue definir mais claramente).

De interesse específico para a nossa pesquisa é a constatação de que em especial os verbos inacusativos admitem dois padrões entoacionais de realização de sentenças neutras, um mais freqüente (em 9 das 15 realizações) que exibe a maior amplitude do movimento de pitch sobre o verbo e outro, menos freqüente (6 ocorrências em 15 sentenças), em que o maior movimento de pitch estaria sobre o sujeito. Esse resultado será retomado na seção 4.2, quando discutiremos situações em que um ou outro desses padrões pode aparecer.

Um resultado adicional interessante do exame dos dados do corpus II que não está contemplado no Gráfico 1 diz respeito à entoação de sentenças que contêm quantificadores indefinidos na posição de sujeito: qualquer que seja o tipo do verbo, a presença de itens como alguns, poucos ou muitos sempre determina um movimento de pitch sobre o sujeito. Em certos casos, pode-se observar adicionalmente um movimento de pitch sobre o verbo e/ou objeto, mas sempre há um movimento sobre o sujeito em todas essas sentenças. No entanto, quando o DP sujeito exibe o determinante indefinido um, os resultados espelham os obtidos quando o DP sujeito porta um determinante definido, isto é, as sentenças grosso modo apresentam padrão descendente quando o verbo é transitivo, ligeiramente ascendente quando o verbo é inergativo (com muitas ocorrências de movimento de pitch sobre o verbo) e duplo movimento quando o verbo é inacusativo.

Podemos agora responder às questões formuladas em (3). Quanto à questão (3a), podemos afirmar que, independentemente do que acontece com os eventos tonais específicos em cada ponto relevante da frase, é possível identificar grandes contornos de pitch sobre alguns dos constituintes da sentença e, visto desse ângulo, o padrão entoacional neutro de sentenças com verbos monoargumentais difere do padrão entoacional que se encontra em 
sentenças transitivas. Internamente ao conjunto dos verbos monoargumentais também existe uma diferença, que diz respeito à presença de um movimento de pitch também sobre o sujeito, em geral menos amplo que o observado sobre o verbo, mas de qualquer modo presente em boa parte das elocuções com verbos inacusativos.

É preciso ainda excluir a hipótese de que a presença de um movimento de pitch sobre o verbo seja de algum modo dependente da presença de um movimento de pitch sobre o DP sujeito, o que poderia ser uma explicação para o padrão encontrado em uma sentença como A Ana morreu ${ }^{6}$. O que se observa, no entanto, é que, aumentado o número de sílabas intervenientes entre a sílaba tônica do sujeito e a do verbo, o mesmo padrão é encontrado, como mostra a Figura 6, que apresenta três sílabas átonas entre as duas sílabas tônicas. Ainda mais, a Figura 6 mostra que é possível um movimento de pitch acentuado sobre o verbo mesmo sem a existência de qualquer movimento similar sobre o sujeito.

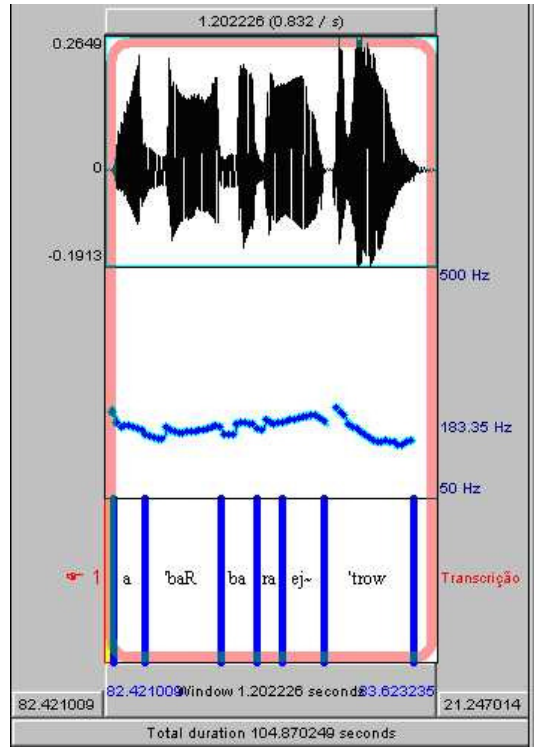

(a)

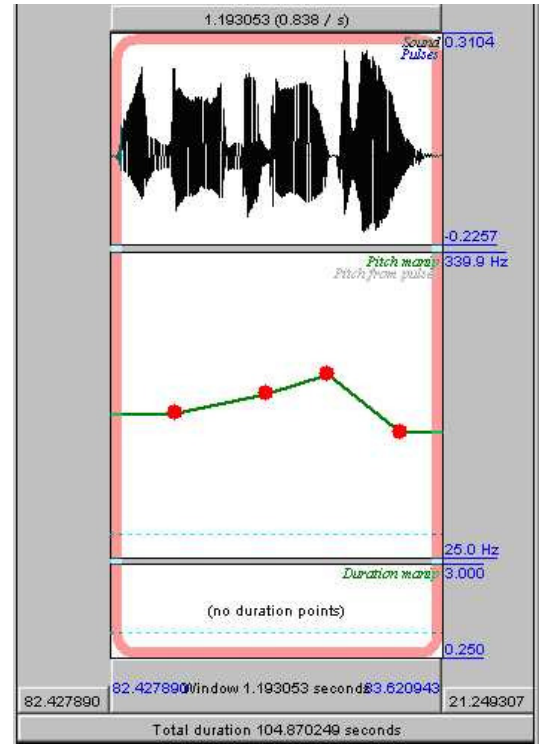

(b)

FIGURA 6

(a) Forma de onda e curva de contorno de pitch original com transcrição fonética e

(b) curva estilizada pelo Momel da sentença: A Bárbara entrou. (lida como manchete de jornal) 
Quanto à segunda questão formulada em (3), podemos dizer que não há diferença sistemática entre DPs definidos e DPs indefinidos se estamos falando de DPs com o determinante indefinido $\mathrm{um}$. Se o que está em jogo é algum outro tipo de determinante, em particular, os quantificadores do tipo muitos ou nenhum, o que temos é sistematicamente um movimento de pitch notável sobre o DP que exibe este quantificador, podendo ocorrer igualmente um movimento de pitch (menor) sobre o VP.

A última parte de nosso corpus se compõe de sentenças com diferentes tipos de verbos que deveriam ser lidas em voz alta no contexto de uma pequena estória que o informante lia primeiro silenciosamente. As estórias tentam criar contextos em que ora um determinado personagem é completamente novo no cenário, ora ele já é mencionado na estória e, portanto, configura-se como um tópico discursivo. O que queríamos testar precisamente com este tipo de corpus era a ligação ou não de cada um dos contornos entoacionais que encontramos nas sentenças SV ditas neutras a contextos discursivos que favoreceriam uma ou outra dessas ordens. A importância dessa discussão se liga à questão sobre a existência mesma de VS em PB, que está na seção 4.1, a seguir.

\section{SOBRE OS DIFERENTES TIPOS DE SV}

\subsection{Uma palavra sobre VS em PB}

A propriedade da inversão do sujeito tem merecido destaque nos estudos gerativistas desde o estudo clássico de Rizzi (1978) - publicado como um capítulo de Rizzi (1982) -, base para muito do que Chomsky (1981) diz sobre o parâmetro do sujeito nulo, na época chamado parâmetro PRO-drop. Fundamentalmente, o que esses estudos apontam é a ligação intrínseca da propriedade de inversão (dita livre) do sujeito e a propriedade do sujeito nulo.

Não é de se estranhar, portanto, que a literatura sobre VS em português brasileiro seja vasta: desde que se constata a perda crescente da possibilidade de sujeitos nulos na língua, é de se perguntar o que ocorre com a propriedade da inversão do sujeito. E, de fato, o que a literatura sobre o assunto tem mostrado é que estas são construções caminhando a passos largos para o desuso no português brasileiro atual, ainda que os diferentes estudos sobre o problema afirmem coisas diferentes sobre as suas (im)possibilidades. Berlinck 
(1988), num estudo já clássico, mostra o percurso diacrônico de perda das estruturas VS em diferentes contextos gramaticais, acentuada especialmente com os verbos transitivos. Vários estudos de Kato (1987, 2000), Kato \& Nascimento (1995) e de Kato \& Tarallo (2003), para citar apenas os mais importantes, confirmam esse resultado, apontando também que as últimas estruturas VS que ainda têm algum fôlego no PB são as estruturas monoargumentais.

Coelho (2000) mostra que, no português falado em Florianópolis, apenas com verbos inacusativos a ordem VS é estatisticamente relevante, e o tipo de nominal que aparece à direita também é significativo: DPs indefinidos (e não-específicos) são preferidos a DPs definidos. Costa et al. (2004) assumem adicionalmente que VS com verbos inacusativos é preferencialmente utilizada em resposta a o que (é) que aconteceu? e não como expressão de foco sobre o sujeito, como resposta a quem (é) que chegou? Por outro lado, Pilati (2004) defende a existência de V(O)S em contextos marcados discursivamente, como na narração de partidas de futebol e mesmo manchetes de jornais, sempre com esta interpretação de frase apresentacional, sendo irrelevante o tipo de DP que aparece como sujeito.

Sem nenhuma pretensão de resenhar toda a literatura sobre o assunto, apenas com base neste breve sumário, já é possível perceber o quão difícil é estabelecer quais são os fatos sintáticos do português brasileiro com respeito a VS. Não vamos fazer aqui nenhuma tentativa de elucidar a questão. Por agora, reteremos apenas as informações menos controversas, que parecem já fazer parte do conhecimento construído sobre VS em PB: os verbos monoargumentais (ainda) têm alguma possibilidade de aceitarem a inversão do sujeito, mas estamos sempre falando de subconjuntos: dos verbos, preferencialmente os verbos inacusativos; dos sujeitos, preferencialmente os DPs indefinidos. Concluiremos (e talvez este seja, sim, um aspecto mais controverso) que DPs definidos como sujeitos de verbos inacusativos têm preferência pela posição pré-verbal.

A pertinência destas observações sobre VS ficará clara na discussão sobre SV que se segue.

\subsection{Ausência de VS e dois padrões de SV}

Se, como discutimos na seção 2, existe uma relação entre o lugar do acento nuclear e a melodia frasal e se, como vimos na seção 3.2, os verbos 
inacusativos em PB apresentam dois diferentes padrões melódicos para as sentenças neutras, então é pertinente examinarmos a discussão que Cinque (1993) faz sobre diferentes padrões de acento no inglês em estruturas SV com verbos inacusativos.

Especificamente, a discussão de Cinque (1993, p. 260) é sobre dois padrões de acento que aparecem no mesmo tipo de contexto "neutro". Os fatos do inglês estão exemplificados em (4) - as sentenças (51) de Cinque (1993, p. 260), nas quais maiúsculas marcam a palavra com o acento principal:
a. Truman DIED
/Truman morreu/
b. JOHNSON died
/Johnson morreu/

Segundo o autor (citando a discussão de Schmerling (1976) sobre estes exemplos), (4a) foi o padrão acentual utilizado para o anúncio da morte de Truman; note-se que ele era parte da pressuposição, porque estava presente com frequiência nos noticiários por conta dos seus problemas de saúde; o que era novo então era a sua morte. Em contrapartida, a sentença com o padrão acentual em (4b) anuncia a morte de Johnson, um fato totalmente inesperado; portanto, ele não poderia ser parte da pressuposição. Assim, embora aparentemente as duas sentenças enunciem um fato novo, elas o fazem diferentemente. Sob o ponto de vista da distribuição do acento, essa diferença é revelada pela proeminência maior presente ora sobre o verbo, ora sobre o sujeito.

Mas se o evento inteiro é novo, por que o acento normal em DIED não é a opção de (4b)? O verbo seria o constituinte mais encaixado e a projeção do acento daria como resultado a sentença toda ser foco. A resposta, argumenta Cinque, pode ser construída a partir da comparação do inglês com o italiano - as sentenças (52) de Cinque (1993, p. 260):
a. Truman è MORTO
/Truman morreu/
b. È morto JOHNSON /Morreu Johnson/ 
Em italiano, a sentença VS é aquela usada para a expressão de um evento totalmente novo, construção em que supostamente o sujeito está em sua posição de base (que é, no caso, a posição de objeto), recebendo assim o acento frasal já que ele é o constituinte mais encaixado do VP. O sujeito préverbal é necessariamente parte da pressuposição, e esta é a razão da inadequação da ordem de palavras de (5a) para a descrição de um evento inteiramente novo. $\mathrm{O}$ autor nota que essas observações estão presentes também no trabalho de Guéron (1980) sobre a distinção entre sentenças predicacionais, como (4a), e sentenças apresentacionais, como (4b), em que o sujeito é o foco (não marcado).

Dado que o inglês não tem VS, o sujeito tem que ser sempre alçado para Spec IP, o que dá lugar a uma sentença predicacional. Se esta não é a interpretação desejada, então parece que a saída é marcar o elemento menos predizível do evento (o sujeito) como foco e tratar o predicado como pressuposto (visto que morrer é algo que pode acontecer a qualquer um, como argumenta Cinque).

Esta discussão de Cinque sobre o italiano e o inglês nos permite predizer o modo como cada uma das línguas representa os interesses pragmáticodiscursivos (como quer que eles devam ser caracterizados). Em particular, o que parece estar em jogo é a capacidade que a língua tem de poder deixar o sujeito na posição de base de modo que esta seja a posição mais encaixada e, portanto, a que recebe o acento frasal. No caso de a língua não dispor dessa opção, deve haver na língua uma estratégia fonológica para resolver a questão - segundo Cinque, por meio de distribuição diferenciada de acento.

O que se pode dizer então sobre o português brasileiro? Na literatura sobre o PB, afirma-se que essa língua manifesta preferência por VS com verbos inacusativos, o que pode ser entendido como uma dificuldade em admitir VS quando o DP sujeito estaria ocupando Spec VP - a posição profunda do argumento externo -, mas com uma relativa facilidade em admitir VS quando o DP estaria ocupando na verdade a posição de argumento interno do verbo. Nessa posição, no entanto, esse DP estaria exposto a uma restrição pouco entendida, mas há muito notada relativa à sua definitude (cf., por exemplo, a discussão de Belletti (1988) sobre o fenômeno).

Observe que, nos casos de "antitópicos", ou seja, de deslocamento à direita do sujeito, o DP sujeito deve ser um tópico discursivo ou parte da situação extralingüística e, portanto, faz necessariamente parte da pressuposição. Não 
são estes os contextos relevantes para essa discussão de Cinque. O VS do português brasileiro é mais parecido com o VS de línguas como o italiano (ainda que seja sempre mais marginal do que no italiano) e em contextos inacusativos. Aqui S é na verdade o objeto profundo, o elemento mais encaixado da sentença, recebendo o acento frasal e qualificando-se como foco, o caso pertinente para Cinque. Mas, se esses são casos, só são plenamente aceitos com um conjunto de verbos (basicamente os inacusativos) e que ainda apresentem um tipo especial de sujeito (um DP indefinido). O que se esperaria é que o PB estivesse mais próximo do inglês do que do italiano, no sentido de desenvolver (ou lançar mão) de uma estratégia acentual para suprir a falta de uma representação estrutural todas as vezes que tiver de lidar com verbos que não são inacusativos e, mesmo com eles, com sujeitos que não são DPs indefinidos.

Agora já podemos apresentar os resultados dos testes que fizemos com o corpus III, que é o conjunto de sentenças lidas como resultado de uma pequena estória que elicitava a produção de sentenças em contextos distintos.

Os resultados, na verdade, são muito menos robustos do que gostaríamos. Relembremos que estamos supondo que, em frases curtas do tipo SV, os movimentos de pitch se correlacionam com a percepção da proeminência acentual, uma hipótese plausível dado o reduzido número de elementos na sentença para serem candidatos a portador do acento. $\mathrm{O}$ que esperaríamos encontrar, se os testes realizados no corpus III são de fato os testes adequados, é um movimento de pitch mais acentuado sobre o sujeito quando este é um elemento absolutamente novo no discurso - no contexto 1 , por exemplo, que é uma frase apresentativa -, mas um movimento de pitch mais acentuado sobre o verbo quando o sujeito já fosse tópico discursivo que é o caso do contexto 6 , em que o sujeito é mencionado diversas vezes na estória. O leitor está convidado então a examinar as Figuras 7 e 8. 


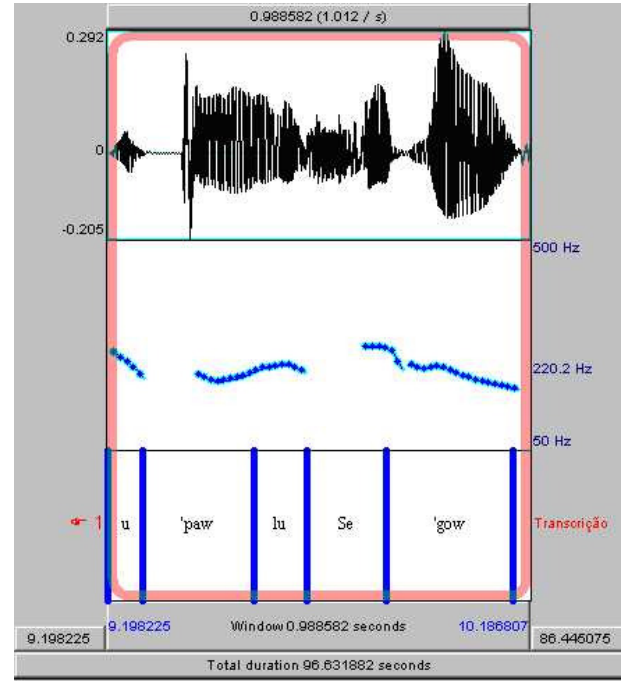

(a)

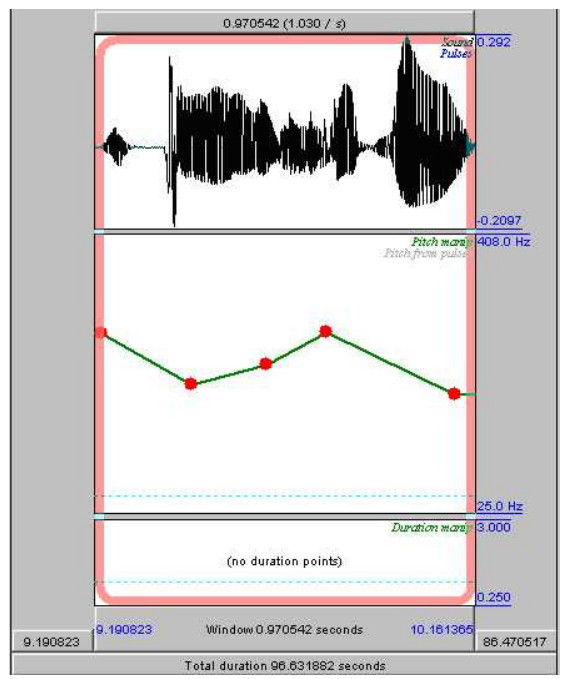

(b)

FIGURA 7

(a) Forma de onda e curva de contorno de pitch original com transcrição fonética e (b) curva estilizada pelo Momel da sentença: O Paulo chegou. (contexto 1).

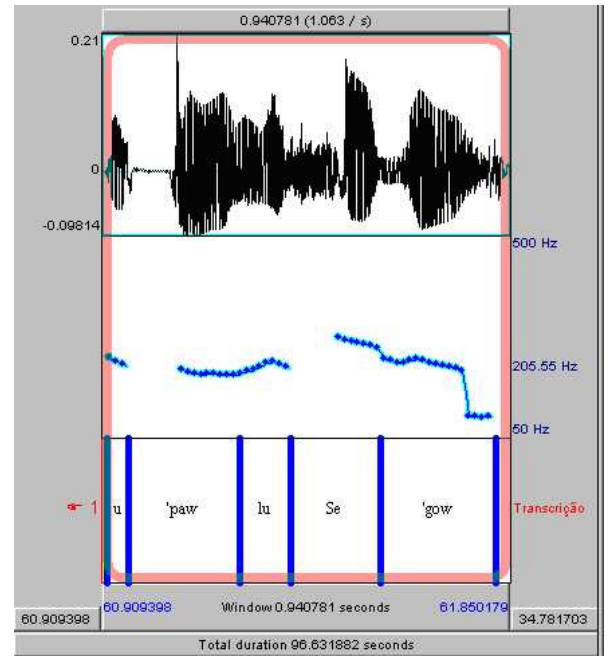

(a)

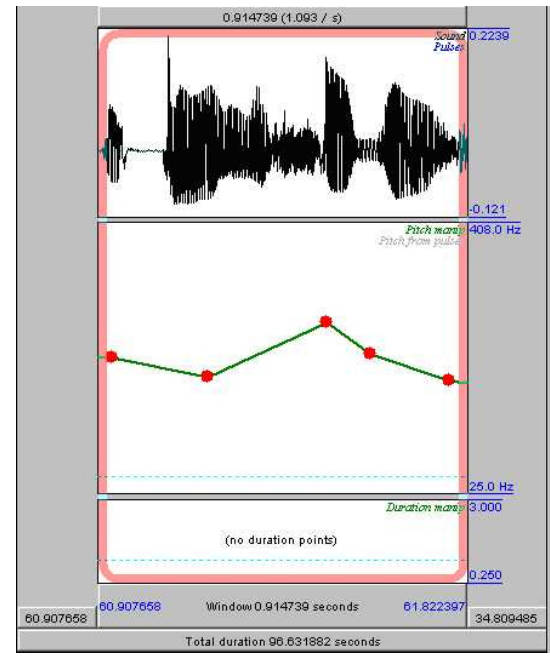

(b)

(a) Forma de onda e curva de contorno de pitch original com transcrição fonética e (b) curva estilizada pelo Momel da sentença: O Paulo chegou. (contexto 6). 
Ainda que, em termos de contornos gerais, as duas figuras se assemelhem bastante (e sejam completamente diferentes da Figura 9 que apresenta foco sobre o sujeito), há uma diferença sutil que vai na direção predita: o contorno de pitch das duas sentenças apresentadas nas Figuras 7 e 8 se assemelham muito no movimento sobre o verbo, mas é possível observar na Figura 7 um movimento ligeiramente mais pronunciado sobre o sujeito do que na Figura 8 , um fato observado em dois dos três informantes.

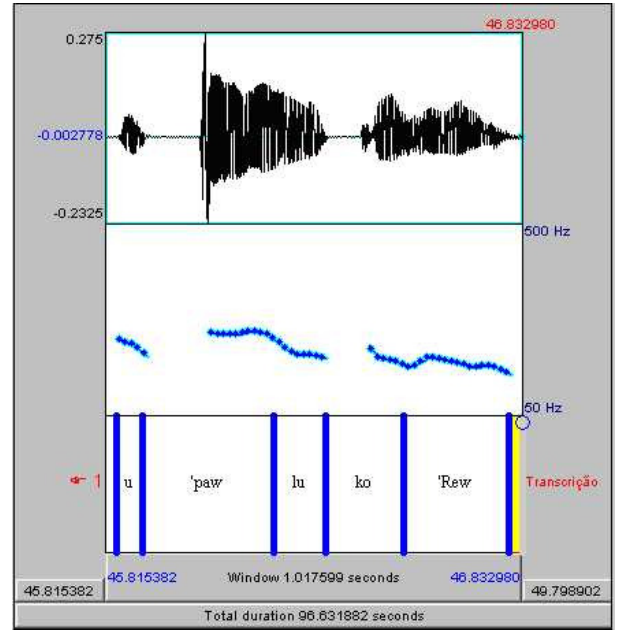

(a)

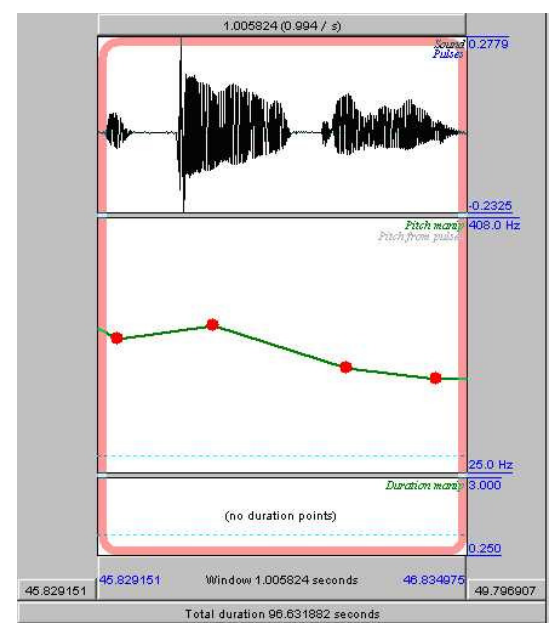

(b)

FIGURA 9

(a) Forma de onda e curva de contorno de pitch original com transcrição fonética e (b) curva estilizada pelo Momel da sentença: $O$ Paulo correu, com foco no sujeito.

O corpus III tentou recriar, nos contextos 7 e 8, o mesmo contraste que existe entre as sentenças do inglês sobre a morte de Truman e de Johnson, apresentando a morte de Tancredo Neves e a de Ayrton Senna. No entanto, os resultados foram muito menos claros e, em certas ocorrências, exatamente o contrário do esperado. É possível que o movimento de pitch que se encontra sobre o verbo na sentença produzida no contexto da morte de Senna se deva ao fato de que, mesmo sem mencionar esse nome na estória, ele vem à mente do falante quando usamos a descrição definida "um piloto de Fórmula 1 que 
se tornou herói nacional" e, assim, o sujeito é de qualquer modo um tópico discursivo. Mais difícil é explicar o movimento de pitch mais pronunciado sobre o DP sujeito Tancredo, salvo fazendo a hipótese de que a estória não é suficiente para lembrar (ou contar) ao informante a presença que Tancredo teve nos noticiários e, dessa maneira, sugerir que ele seja encarado como um tópico discursivo.

Talvez o fato mais significativo com respeito a essas duas últimas estórias (que eram as que pensávamos ser as mais efetivas!) seja a ocorrência curiosa de um dos informantes produzir a sentença com uma melodia, em seguida se corrigir e produzir a sentença com outra melodia, e isso em ambos os casos! Essa hesitação mostra que o falante está consciente de que existem duas melodias, mas, quando é convidado a produzir a sentença com a melodia adequada, ele não sabe exatamente qual deve produzir.

Utilizaremos a nosso favor, então, o benefício da dúvida, absolutamente cientes de que os resultados dos testes do corpus III são meramente indicativos e que devem ser reproduzidos e melhorados para que as conclusões sejam seguras e palpáveis.

\section{Primeiras conclusões e direções possíveis para trabalhos futuros}

Esperamos ter assentado alguns pontos neste trabalho, alguns dos quais eventualmente já estão expostos na literatura especializada e aqui encontram respaldo:

1. Sentenças com foco sobre o sujeito apresentam um padrão entoacional absolutamente distinto das sentenças que não apresentam foco em nenhum de seus constituintes, qualquer que seja a classe verbal e o tipo de DP utilizado como sujeito.

2. Quando a sentença não apresenta foco em nenhum de seus constituintes, os verbos monoargumentais apresentam um contorno de pitch que é distinto do dos verbos transitivos, em particular não apresentando uma curva inteiramente descendente, como é o caso das sentenças transitivas. Internamente ao conjuntos dos verbos monoargumentais, também se observa uma diferença: as sentenças com verbos inergativos apresentam no geral um padrão entoacional ligeiramente ascendente, com movimento 
de pitch sobre o verbo, mas as sentenças inacusativas apresentam movimentos de pitch sobre ambos, o sujeito e o verbo, configurando dois movimentos, e ora um deles é o mais pronunciado, ora o outro. Essas configurações foram obtidas tanto na leitura de sentenças quanto na resposta a perguntas como o que aconteceu?

3. Estes padrões mencionados assim são obtidos seja com DPs sujeito definidos, seja com DPs sujeito indefinidos com o determinante um. Se o determinante é um quantificador como muitos ou algum, a sua presença implica movimento acentuado de pitch sobre o sujeito.

4. Tentativamente, podemos sugerir que as duas melodias identificadas nas sentenças inacusativas se correlacionam com a necessidade discursiva de tratar o sujeito como tópico ou não, uma questão intimamente relacionada com a perda das estruturas VS no PB atual.

É evidente que vários outros experimentos devem ainda ser elaborados para que possamos afirmar com segurança total que o fenômeno observado nesta pesquisa existe, que é robusto e que tem as restrições e as características mencionadas. Ainda que a existência de dois padrões entoacionais já tivesse sido observada em outros experimentos que fizemos, várias propriedades não haviam sido notadas (e algumas das que verificamos estavam equivocadas, seja porque o corpus não permitia avaliar a extensão do fenômeno com clareza, seja porque variáveis diversas não devidamente controladas nos impediam de formular a generalização adequada.

Acreditamos ter agora montado uma bateria de testes que pode conduzir a respostas seguras para as nossas questões de base, mas ainda será necessário averiguar:

1. se os resultados de sentenças lidas se encontram também na produção espontânea. É preciso pensar um modo de obter esses dados.

2. se a descrição padrão dos eventos tonais que se encontra na literatura é reveladora de detalhes das curvas de pitch que podem alargar a nossa compreensão dos fenômenos aqui estudados. O próximo passo será a descrição detalhada das curvas apresentadas nos dados.

3. se os segmentos utilizados nos exemplos de fato não influenciam o Momel no cálculo que faz para a estilização. Num primeiro momento pensamos 
que era possível não ter que controlar essa variável, já que o Momel fornece curvas contínuas, mas agora nos perguntamos se esta é a decisão mais segura para tomar a priori.

4. dado que, para o estabelecimento dos padrões melódicos, os verbos monoargumentais se comportam de maneira uniforme, se também com os verbos inergativos se poderia identificar duas melodias que se associam a diferentes informações discursivas, já que a perda de VS é ainda mais clara com essa classe verbal.

Finalmente, é imprescindível um estudo acurado sobre as possibilidades entoacionais (e interpretativas) para as sentenças VS do português brasileiro, uma tarefa a que nos dedicaremos tão logo o padrão SV esteja minuciosa e adequadamente descrito.

\section{NOTAS}

* Gostaríamos de agradecer a todos os que nos deram sugestões para a melhoria do trabalho, a começar pela audiência do encontro do GT de Teoria da Gramática realizado em Ouro Preto, em dezembro de 2005, em especial para Flaviane Fernandes e para a debatedora do trabalho, Filomena Sãndalo. Os agradecimentos mais efusivos, no entanto, vão para os dois pareceristas anônimos desta Revista, que fizeram leituras rigorosas e comentários generosos ao texto original, sem os quais o presente artigo não teria boa parte dos acertos que têm. Os erros, evidentemente, permanecem sendo de nossa inteira responsabilidade.

${ }^{1}$ Esta não é, evidentemente, uma conclusão necessária, como mostra a proposta de Zubizarreta (1998), que supõe um momento da derivação em que sintaxe, discurso e fonologia "conversam". Aqui assumiremos uma perspectiva mais convencional, ainda que em vários pontos apresentemos um diálogo com as idéias de Zubizarreta (1998).

${ }^{2} \mathrm{Na}$ verdade, as sentenças apresentadas por Tenani (2002) nem sempre são efetivamente sentenças transitivas, mas em geral contêm algum outro elemento após o verbo, como por exemplo $O$ vendedor chegou atrasado ou $A$ casa de Pedro ficou pronta.

${ }^{3}$ As transcrições fonéticas não são detalhadas, constituindo-se assim em transcrições fonéticas largas. 
${ }^{4}$ Marginalmente também testamos foco sobre todo o predicado com verbos transitivos fazendo a pergunta o que a Mara fez?, mas este não foi um contexto gramatical explorado sistematicamente sobretudo pela falta de naturalidade de pares como $O$ que a Maria fez?/ A Maria chegou.

${ }^{5}$ Agradecemos aqui a um dos pareceristas anônimos que nos chamou a atenção para esta necessidade imperativa.

${ }^{6}$ Essa possibilidade foi aventada por um dos pareceristas anônimos, que a formulou em termos de eventos tonais específicos: a presença de um tom alto no verbo pode ser reflexo da presença do tom alto sobre o sujeito se for muito reduzido o número de sílabas que separa as sílabas tônicas do sujeito e do verbo.

\section{REFERÊNCIAS BIBLIOGRÁFICAS}

BELLETTI, A. The case of unaccusatives. Linguistic Inquiry 19, p 1-34, 1988. BERLINCK, R. de A. A ordem V SN no português brasileiro: sincronia e diacronia. 1988. Dissertação (Mestrado). Unicamp - IEL, Campinas.

CHOMSKY, N. Lectures on government and binding. Dordrecht: Foris, 1981. CINQUE, G. A Null Theory of Phrase and Compound Stress. Linguistic Inquiry, 24, p. 239-297, 1993.

COELHO, I.L. A ordem VDP em construções monoargumentais: uma restrição sintático-semântica. 2000. Tese (Doutorado). UFSC - CCE, Florianópolis.

COSTA, J.; OLIVEIRA, F.; COELHO, I.; FIGUEIREDO SILVA, M.C. On VS order and null subjects in European and Brazilian Portuguese. 2004 (manuscrito não publicado).

COSTA, J.; FIGUEIREDO SILVA, M.C. On the (in)dependence relations between syntax and pragmatics. In: MOLNÁR, V. \& S. WINKLER (eds.) The Architecture of Focus. Studies in Generative Grammar 82. Mouton de Gruyter, Berlim, p. 83-104, 2006.

FROTA, S. Prosody and Focus in European Portuguese. 1998. Tese (Doutorado). Univesidade de Lisboa - Faculdade de Letras, Lisboa.

GONÇALVES, C. A. O fenômeno da focalização e a interface fonologia-sintaxe. D.E.L.T.A., v. 15, n. 2, p. 319-342, 1999. 
KATO, M. Inversão da ordem SV em interrogativas no português. D.E.L.T.A., v. 3, n. 2, p. 243-252, 1987.

. A restrição da monoargumentalidade da ordem VS no português do Brasil. Fórum Lingüístico, v. 2, n.1, p.97-127, 2000.

; NASCIMENTO, M. O estatuto dos nominais pós-verbais dos verbos inacusativos. Revista de Estudos da Linguagem, n. 3, p. 31-74, 1995.

; TARALLO, F. The loss of VS syntax in Brazilian Portuguese. In: MÜNSTER, E. (Ed.) Dialogue between schools: sociolinguistics, conversational analysis and generative theory in Brazil. Münster: Nodus Publications, 2003. p. 121-129.

LADD, R. Intonational Phonology. Cambrigde: Cambridge University Press, 1996.

MORAES, J. Intonation in Brazilian Portuguese. In: HIRST, D.; A. DI CRISTO (Orgs.). Intonation System. A Survey of Twenty Languages. Cambridge UK: Cambridge University Press, 1998. p. 179-193.

PILATI, E. Sujeitos pós-verbais no português brasileiro, no francês e no italiano. Apresentação feita no XIC Encontro Nacional da ANPOLL, GT Teoria da Gramática, Maceió, Alagoas, 2004.

RIZZI, L. Issues in Italian Syntax. Dordrecht: Foris, 1982

SANDALO, F. (2004) Fonologia Prosódica e Teoria da Otimalidade: reflexões sobre a interface sintaxe e fonologia na formação de sintagmas fonológicos. Disponível em: <http://www.ime.usp.br/ tycho/participants/sandalo/ sandalo 01.htm>

SANDALO, F; TRUCKENBODT, H. Some Notes on Phonological Phrasing in Brazilian Portuguese. D.E.L.T.A., 19:1, p. 1-30, 2002.

SELKIRK, E. Sentence prosody: Intonation, stress, and phrasing. In: GOLDSMITH, J. (Ed.) The handbook of phonologycal theory. Oxford: Blackwell, 1995.

TENANI, L. Domínios prosódicos no português do Brasil: implicações para a prosódia e para a aplicação de processos fonológicos. 2002. Tese (Doutorado). Unicamp - IEL, Campinas.

ZUBIZARRETA, M.L. Prosody, Focus, and Word Order. Cambridge (Mass.): The MIT Press, 1998. 


\section{ANEXO 1 - OS CORPORA}

I. Responda às perguntas seguintes, repetindo a estrutura sentencial completa (o sujeito, o verbo ou objeto da pergunta) e inserindo como resposta os itens lexicais entre parênteses, conforme o exemplo:

\section{Exemplo: Quem levou um tombo? (aquele menino)} Resposta: Aquele menino levou um tombo.

1. Quem lavou a luva?

2. O que a menina fez?

3. O que aconteceu?

4. Quem levou o bolo?

5. O que um menino fez?

6. O que aconteceu?

7. Quem chegou?

8. O que aconteceu?

9. Quem morreu?

10. O que aconteceu?

11. Quem viajou?

12. O que aconteceu?

13. Quem nadou?

14. O que aconteceu? (a Mara lavou a luva)

(a menina lavou a luva)

(o garoto lavou a luva) (um menino levou o bolo) (um menino levou o bolo) (um menino levou o bolo) (o carteiro chegou) (o carteiro chegou) (um menino morreu) (um menino morreu) (uma garota viajou) (uma garota viajou) (a Mara nadou) (a Mara nadou)

II. Leia as seguintes frases da maneira mais natural possível:

1. A menina lavou a luva.

2. Aquela garota ganhou um livro.

3. Esse menino levou um tombo.

4. A Bárbara guardou o relatório.

5. A Marina convidou o Paulo.

6. Um menino comeu o bolo.

7. Algumas meninas venderam as uvas.

8. Poucas garotas venceram o desafio.

9. Nenhuma menina chutou o balde.

10. Muitos homens pegaram o panfleto.

11. A Cândida nadou.

12. Aquela menina chorou.

13. Esse menino dormiu.

14. A Mara sonhou.

15. O menino correu. 
16. Um garoto telefonou.

17. Nenhuma garota espirrou.

18. Alguns meninos tossiram.

19. Poucos garotos viajaram.

20. Muitas mulheres trabalharam.

21. O garoto cresceu.

22. Aquele homem morreu.

23. Essa mulher renasceu.

24. A Bárbara entrou.

25. A Ana caiu.

26. Um menino nasceu.

27. Nenhum homem saiu.

28. Muitas mulheres chegaram.

29. Poucos homens vieram.

30. Alguns produtos descongelaram.

III. Imagine que você está na seguinte situação:

1. Você está na casa de uns amigos que têm vários cachorros. De repente, os cachorros começam a latir e a dona da casa te pede pra olhar pela janela o que está acontecendo pros cachorros latirem tanto. Você olha e vê um carro estacionado, de um outro amigo dos donos da casa, que você conhece.

Você diz:

O Paulo chegou.

2. O seu chefe abre a porta da sua sala e pergunta se você conhece alguém que fale inglês. Você, sabendo que a Mara morou nos EUA, diz:

A Mara fala inglês.

3. Alguém abre a porta da sua sala e pergunta se você sabe o que a Mara ganhou no sorteio que teve no dia anterior. Você responde:

A Mara ganhou uma malha.

4. Teve uma gincana esportiva na firma em que você trabalha. Cada um teve que ir lá fazer algum esporte. Você jogou xadrez pelo setor. Alguém vem perguntar o que a Mara fez pelo setor.

Você responde:

A Mara nadou.

5. Uma outra pessoa chega depois na conversa e então te pergunta quem correu pelo setor. Você responde:

O Paulo correu. 
6. Tem alguém que vem reclamar de um produto que comprou na loja em que você trabalha, mas é preciso que o Paulo, o seu chefe, assine a troca. A pessoa está com pressa e você está explicando que é imprescindível que o Paulo assine a troca. Nisso você vê pela janela o Paulo estacionando o carro e diz:

O Paulo chegou.

7. Nos anos 80 , não havia eleição direta; os presidentes eram eleitos por um colégio eleitoral. O primeiro presidente civil eleito neste sistema foi Tancredo Neves. Mas, antes da sua posse, em março de 1985, ele foi internado no hospital muito doente e ali ficou por um mês mais ou menos. Imagine que você é o apresentador do noticiário que, no dia 21 de abril, deve dar a notícia da morte dele.

Você diz:

O Tancredo morreu.

8. Nos anos 90 , o Brasil tinha um piloto de fórmula um que se tornou herói nacional. No entanto, em meado de 1994, este piloto sofreu um acidente e morreu. Imagine que você é o apresentador do noticiário. Você diz:

O Senna morreu. 